\title{
$\beta$-Hydroxybutyrate (BHB) and glucose concentrations in the blood of dairy calves as influenced by age, vaccination stress, weaning, and starter intake including evaluation of BHB and glucose markers of starter intake
}

\author{
F. X. Suarez-Mena, ${ }^{1}$ W. Hu, T. S. Dennis, T. M. Hill, and R. L. Schlotterbeck \\ Nurture Research Center, Provimi, Brookville, OH 45309
}

\begin{abstract}
The objective of this research was to determine how blood $\beta$-hydroxybutyrate (BHB) and glucose are affected by age, time of day, stress, weaning, forced intake restriction, and voluntary starter intake in calves between 1 and 9 wk of age, and to evaluate if either is an acceptable proxy for starter intake. Holstein calves were fed a $27 \%$ crude protein, $17 \%$ fat milk replacer at $660 \mathrm{~g}$ of dry matter daily along with free-choice starter and water. Calves were weaned on d 42 . Jugular blood was sampled at 0800, 1200, and $1600 \mathrm{~h}$, and within 5 min of sampling BHB, and glucose concentrations were estimated using test strips (Nova Max Plus meter, Nova Biomedical Corporation, Waltham, MA). Age effects and time of day were estimated by sampling blood weekly (d 6, 13, 20, 27, 34, 41, and 48). To determine vaccination stress, a Pasteurella vaccine was administered after blood sampling at $0800 \mathrm{~h}$ on d 36. Effect of voluntary starter intake was tested by selecting calves for low and high intakes (d 35 to 39) and sampling on d 40,41, 43, and 44. Starter intake restriction was tested by restricting intake in half of the calves and sampling on d 60 and 61. Data were analyzed with repeated measurements in a mixed model procedure with either within-calf effect (day or week) or within-calf effects (hour, and day or week) included in the model. Time of day did not affect blood BHB and glucose in the first 6 wk. Blood BHB was greater in wk 7 versus wk 1 to 6 . Blood glucose was greater in the first $5 \mathrm{wk}$ compared with wk 6 and 7. Blood BHB increased and glucose decreased with increasing starter intake. Blood BHB declined due to vaccination, but glucose was unaffected. Starter intake restriction reduced BHB for $3 \mathrm{~d}$ and glucose for $2 \mathrm{~d}$ after restriction. Both were affected by time of day. Around weaning (d 40 to 44), BHB and glucose increased with increasing starter intake. In this research, neither blood BHB nor glucose was a good
\end{abstract}

Received October 19, 2016.

Accepted December 11, 2016.

${ }^{1}$ Corresponding author: xsuarez@provimi-na.com proxy for starter intake. Blood BHB was positively and glucose negatively related to starter intake; however, relationships were weak, variable, and affected by time of day, stress, and intake restriction. Over $30 \%$ of calves tested $\leq 0.2 \mathrm{mmol} / \mathrm{L}$ BHB when consuming $>1,250 \mathrm{~g} / \mathrm{d}$ of starter, and test strip increments were $0.1 \mathrm{mmol} / \mathrm{L}$, which represented $>25 \%$ of the mean blood BHB concentration. In this study, neither blood BHB nor glucose was an acceptable proxy for estimating starter intake.

Key words: blood $\beta$-hydroxybutyrate, glucose, intake, dairy calf

\section{INTRODUCTION}

The development of the rumen and with it the readiness of the calf's digestive system to obtain the nutrient requirements for maintenance and growth from solid feed, after weaning, is dependent on starter grain consumption pre-weaning. Butyrate, product of grain fermentation in the rumen, is pivotal for the development of the ruminal epithelium. Along with papillae growth and development of the digestive system, the metabolism of the calf also changes. The hepatic metabolic activity of the calf shifts from glycolytic to gluconeogenic as the liver nutrient supply changes from glucose in the preruminant calf to short-chain fatty acids from ruminal fermentation in the ruminant calf. The relationships between nutrient supply, rumen development, and hepatic metabolism were elucidated in the review by Baldwin et al. (2004).

Because of the relationship between starter intake and rumen development (Baldwin et al., 2004; Suarez-Mena et al., 2011), starter intake would be a good proxy for rumen development. However, starter intake can be difficult to measure on-farm in times of rain when the feed is wet and when labor is limited or poorly trained. Individual starter intake would be even harder to measure in group housing systems (Deelen et al., 2016). Deelen et al. (2016) proposed that blood BHB could be used to determine when a dairy calf can be weaned because BHB was positively correlated with starter intake by the calf. Quigley et al. (1991, 
1994) also reported a positive relationship with blood BHB and also a negative relationship with blood glucose with age and starter intake. However, the research did not evaluate the effects that sampling time of day, stress, weaning, or intake restriction could have on these measurements. In calves fed only milk replacer (MR), blood BHB has been reported to increase to approximately $190 \%$ and glucose to approximately $140 \%$ of pre-meal concentrations $1 \mathrm{~h}$ after a meal (Senn et al., 2000), suggesting milk or MR intake may interfere with using blood BHB and glucose to predict starter intake. A proxy for starter intake would have value to the farm manager, farm advisor, and veterinarian. Inadequate starter intake at time of weaning can be associated with poor performance postweaning (Hill et al., 2016). In cases where large amounts of milk or MR are fed, starter intake can be very low pre-weaning and increase rapidly during reduction in allotted milk or MR and postweaning (Hill et al., 2006). This rapid change in starter intake also makes it difficult to measure starter intake accurately on-farm.

Two commercially available test strip systems (Abbott Precision Xtra from Abbott Diabetes Care Inc., Alameda, CA; Nova Max Plus from Nova Biomedical Corporation, Waltham, MA) have been evaluated as accurate and precise by the FDA $(2015 \mathrm{a}, \mathrm{b}, \mathrm{c}, \mathrm{d})$ and other laboratories (Iwersen et al., 2009; Klehr et al., 2015; Pineda and Cardoso, 2015) for evaluating blood BHB and glucose in humans and bovine. Four systems are available and reliable for testing BHB in cows (Klehr et al., 2015; Pineda and Cardoso, 2015; Bach et al., 2016). These quick test systems make analysis of blood BHB and glucose somewhat practical on farms. Therefore, the objectives of this observational research were to determine how blood BHB and glucose are affected by age, time of day when blood was sampled, stress, weaning, and intake restriction, and correlate blood BHB and glucose with starter intake in calves between 1 and 9 wk of age.

\section{MATERIALS AND METHODS}

\section{Calves, Facility, and Feeding}

Calves were cared for by acceptable practices as described in the Guide for the Care and Use of Agricultural Animals in Research and Teaching (FASS, 2010) and under the approval of the animal care and use committee of the research unit. Male Holstein calves (initially 3 to $4 \mathrm{~d}$ of age) from a single dairy farm were transported $3.5 \mathrm{~h}$ to the Nurture Research Center in southwest Ohio. At approximately midday the day after arrival, calves were weighed, blood was sampled from a jugular vein, serum was harvested, and serum protein concentration was immediately measured using an optical refractometer (Atago USA Inc., Bellevue, WA).

Calves were housed in $1.2 \times 2.4 \mathrm{~m}$ individual pens with a coarse-rock, tile-drained floor bedded with straw in a curtain-sided, naturally ventilated barn with no added heat. Calves were castrated and dehorned on d 36 of the trial. Vaccines and medical treatments were based on the recommendations of a veterinarian and are described in Hill et al. (2006). Calves were fed 660 g of DM daily of a $25 \% \mathrm{CP}, 17 \%$ fat MR powder (Table 1) the first $39 \mathrm{~d}$ divided into 2 equal meals at 0630 and $1615 \mathrm{~h}$, and fed $330 \mathrm{~g}$ of DM daily at $0630 \mathrm{~h}$ on d 40, 41, and 42 . Calves were also fed a $20 \% \mathrm{CP}$ textured starter (42\% starch) and water free choice until d 56. The formulas of the MR and starter were the same as fed in trial 2 by Hill et al. (2009). From d 56 to 65, chopped grass hay was offered ad libitum with free-choice starter and water. Starter and hay were fed between 1100 and $1145 \mathrm{~h}$ daily. Two groups of calves were used for this research received $10 \mathrm{wk}$ apart. For the first group of calves, the average temperature was $21^{\circ} \mathrm{C}$ (range of 7 to $32^{\circ} \mathrm{C}$ ) and the average relative humidity was $83 \%$ (range of 28 to 100\%). For the 9-d measurement period of the second group of calves, the average temperature was $23^{\circ} \mathrm{C}$ (range of 13 to $34^{\circ} \mathrm{C}$ ) and the average relative humidity was $81 \%$ (range of 37 to $100 \%$ ). Feed offered and refused were weighed daily at $1630 \mathrm{~h}$. Calves were weighed at the beginning and weekly throughout the trial. In each blood sampling day, jugular blood was collected by venipuncture at 0800,1200 , and $1600 \mathrm{~h}$, and within 5 min of sampling, BHB and glucose concentrations were estimated using test strips (Nova Max Plus meter, Nova Biomedical, MA).

\section{Group 1: Effect of Age, Time of Day, Stress, Starter Intake}

Effect of age on blood BHB and glucose was determined in 6 calves randomly selected from 50 calves within $2 \mathrm{~d}$ of age of each other. Blood was sampled weekly on d $6,13,20,27,34,41$, and 48 . To determine vaccination stress, a Pasteurella vaccine (Presponse HM, Boehringer Ingelheim Vetmedica Inc., St. Joseph, MO) was administered after blood sampling at $0800 \mathrm{~h}$ on d 36 on the same 6 calves. Blood was collected at 1200 and $1600 \mathrm{~h}$ following vaccination. This vaccine creates a fever and lethargy in calves that lasts for 12 to $36 \mathrm{~h}$ and was used to elicit stress. On d 48, six additional calves from the original set of 50 calves were bled to increase the number of observations after weaning.

The effect of starter restriction was determined postweaning in the same 12 calves as above. Half of the calves were randomly selected to have their starter 
intake restricted to $1,150 \mathrm{~g}$ of $\mathrm{DM}$ from starter along with free-choice hay and water on d 60 and 61 of the trial. Otherwise starter, hay, and water were offered ad libitum. Blood was sampled on d 61 through 65 at 0800, 1200, and $1600 \mathrm{~h}$.

\section{Group 2: Weaning Transition}

To determine the effects of voluntary starter intake and weaning transition, 6 calves were selected from a second group of 50 calves. Calves were selected for either low or high intake based on starter intake from $\mathrm{d}$ 35 to 39 before the target weaning date of $\mathrm{d} 42$. Blood was sampled at 0800,1200 , and $1600 \mathrm{~h}$ on d 40 and 41 (pre-weaning) and d 43 and 44 (postweaning).

\section{Feed Analysis}

Composites of feed samples taken from every other bag of MR and starter and the bale of hay were dried, ground, stored frozen, and subsequently analyzed (AOAC International, 2000) for DM (oven method 930.15), CP (Kjeldahl method 988.05), fat (alkaline treatment with Roese-Gottlieb method 932.06 for MR; diethyl ether extraction method 2003.05 for starters and hay), starch ( $\alpha$-amylase method; Hall, 2009), and sugar (Dubois et al., 1956). The starter and hay were analyzed for NDF with ash by the procedure of Van Soest et al. (1991) without sodium sulfite or $\alpha$-amylase, and ADF with ash (Robertson and Van Soest, 1981).

\section{Statistics}

All data were analyzed using the MIXED procedure in SAS (SAS Enterprise Guide 5.1, SAS Institute Inc., Cary, NC). No outliers were detected and removed from visual observations of the studentized residuals. Significance was defined as $P \leq 0.05$, whereas $0.05<P \leq 0.10$ was considered to indicate a trend toward a significant effect. Model 1 was

$$
\begin{aligned}
\mathrm{Y}_{\mathrm{ijk}}= & \mu+\mathrm{T}_{\mathrm{i}}+\mathrm{H}_{\mathrm{j}}+\mathrm{D}_{\mathrm{k}}+(\mathrm{T} \times \mathrm{H})_{\mathrm{ij}}+(\mathrm{T} \times \mathrm{D})_{\mathrm{ik}} \\
& +(\mathrm{H} \times \mathrm{D})_{\mathrm{jk}}+(\mathrm{T} \times \mathrm{H} \times \mathrm{D})_{\mathrm{ijk}}+\mathrm{e}_{\mathrm{ijk}},
\end{aligned}
$$

where $\mu=$ overall mean; $T_{i}=$ effect of treatment (vaccination stress or restricted intake) $\mathrm{i} ; \mathrm{H}_{\mathrm{j}}=$ effect of measure time 1 (hour, day, or week) j; $D_{k}=$ effect of measure time 2 (hour, day, or week) $\mathrm{k} ;(\mathrm{T} \times \mathrm{H})_{\mathrm{ij}}=$ effect of interaction between treatment $i$ with measure time 1 $\mathrm{j} ;(\mathrm{T} \times \mathrm{D})_{\mathrm{ik}}=$ effect of interaction between treatment i with measure time $2 \mathrm{k} ;(\mathrm{H} \times \mathrm{D})_{\mathrm{jk}}=$ effect of interaction between measure time $1 \mathrm{j}$ with measure time $2 \mathrm{k}$; ( T $\times \mathrm{H} \times \mathrm{D})_{\mathrm{ijk}}=$ effect of interaction among treatment $\mathrm{i}$, measure time $1 \mathrm{j}$, and measure time $2 \mathrm{k}$; and $\mathrm{e}_{\mathrm{ijk}}=$ error term, assuming $N\left(0, \sigma^{2}\right)$, where $\sigma^{2}$ is variance. This was a mixed model with repeated measures. Calf was treated as a random variable. The complete and reduced models from the full model above were used accordingly based upon different studies. Within-calf effects included measuring time either (1) in day or week, or (2) in hour, and day or week. Appropriate covariance structures were selected based on the goodness-of-fit criteria (Littell et al., 1998). Least squares means were separated using the PDIFF with no ADJUST option being specified.

Model 2 was

$$
\mathrm{Y}_{\mathrm{ij}}=\mathrm{B}_{0}+\mathrm{B}_{1} \mathrm{X}_{\mathrm{ij}}+\mathrm{s}_{\mathrm{i}}+\mathrm{e}_{\mathrm{ij}},
$$

where $\mathrm{i}$ is $1,2, \ldots$, calves, $\mathrm{j}$ is $1,2, \ldots, \mathrm{n}_{\mathrm{i}}$ observa-

\begin{tabular}{|c|c|c|c|c|c|}
\hline \multirow[b]{2}{*}{ Item } & \multicolumn{3}{|c|}{ Group 1} & \multicolumn{2}{|c|}{ Group 2} \\
\hline & $\mathrm{MR}^{1}$ & Starter $^{2}$ & $\mathrm{Hay}^{3}$ & $\mathrm{MR}^{1}$ & Starter $^{2}$ \\
\hline $\begin{array}{l}\text { DM, \% } \\
\text { DM basis \% }\end{array}$ & 96.8 & 87.4 & 87.6 & 96.1 & 87.5 \\
\hline $\begin{array}{l}\text { DM basis, \% } \\
\text { CP }\end{array}$ & & & & & \\
\hline $\begin{array}{l}\text { CP } \\
\text { Fat }\end{array}$ & $\begin{array}{l}27.0 \\
18.1\end{array}$ & $\begin{array}{r}20.9 \\
3.9\end{array}$ & $\begin{array}{r}13.2 \\
3.3\end{array}$ & $\begin{array}{l}25.6 \\
181\end{array}$ & $\begin{array}{r}20.4 \\
3.7\end{array}$ \\
\hline $\mathrm{ADF}$ & - & 6.9 & 39.6 & - & 7.7 \\
\hline $\mathrm{NDF}$ & - & 16.9 & 59.7 & - & 14.4 \\
\hline Ash & 6.78 & 6.99 & 6.09 & 6.63 & 6.75 \\
\hline Calcium & 0.84 & 0.81 & 0.41 & 0.71 & 0.88 \\
\hline Phosphorus & 0.63 & 0.58 & 0.34 & 0.61 & 0.60 \\
\hline Starch & - & 42.2 & - & - & 40.2 \\
\hline Calculated ME, Mcal $/ \mathrm{kg}$ & 4.7 & 3.2 & 2.3 & 4.7 & 3.2 \\
\hline
\end{tabular}
tions within calf $\mathrm{i}, \mathrm{B}_{0}$ is the overall intercept among

Table 1. Analyzed nutrient composition of feeds

${ }^{1}$ Based on whey, whey protein concentrate, and lard.

${ }^{2} \mathrm{~A}$ textured feed based on whole corn, whole oats, and soybean meal.

${ }^{3}$ Chopped grass hay. 
calves (fixed effect), $\mathrm{B}_{1}$ is the slope of $\mathrm{Y}$ (blood BHB or glucose) on $\mathrm{X}$ (starter DMI) among calves (fixed effect), $s_{i}$ is the random intercept effect of calf $i$, and $\mathrm{e}_{\mathrm{ij}}$ is the error term, assuming $N\left(0, \sigma^{2}\right)$. This mixedeffects regression model had both fixed (i.e., intercept and slope) effects and a random intercept effect of calf for independent variables. Response variables were adjusted for random calf effect, and thus the adjusted response variables were used to calculate coefficients of determination (i.e., $\mathrm{R}^{2}$ ).

\section{RESULTS AND DISCUSSION}

\section{Calf Description}

Initial calf BW in group 1 was $44 \pm 1.7 \mathrm{~kg}$ and initial serum protein averaged $5.3 \pm 1.1 \mathrm{mg} / \mathrm{dL}$. Over the 9 -wk trial calf ADG was $678 \pm 39 \mathrm{~g} / \mathrm{d}$. The average BW in group 2 at d 40 was $65 \pm 4.3 \mathrm{~kg}$. On d 0 , the BW averaged $43 \pm 2.6 \mathrm{~kg}$ and serum protein $5.2 \pm 1.9$ $\mathrm{g} / \mathrm{dL}$.

\section{Effect of Age and Sampling Time of Day}

Blood BHB ranged from 0.0 to $0.7 \mathrm{mmol} / \mathrm{L}$. Blood glucose ranged from 49 to $125 \mathrm{mg} / \mathrm{dL}$. Blood BHB and glucose did not differ $(P>0.1)$ due to sampling time of day. Blood BHB for the first 6 wk did not differ and were lower $(P<0.001)$ than in wk 7 (Table 2). Blood glucose values during the first $5 \mathrm{wk}$ did not differ and

Table 2. Blood BHB and glucose concentrations by hour of day and week of age in 6 calves in group 1

\begin{tabular}{llcc}
\hline Item & $\begin{array}{c}\mathrm{BHB},{ }^{1} \\
\mathrm{mmol} / \mathrm{L}\end{array}$ & $\begin{array}{c}\text { Glucose }{ }^{2} \\
\mathrm{mg} / \mathrm{dL}\end{array}$ & $\begin{array}{c}\mathrm{DMI}{ }^{3} \\
\mathrm{~g} / \mathrm{d}\end{array}$ \\
\hline Time, h & & & \\
0800 & 0.13 & 94.3 & - \\
1200 & 0.12 & 94 & - \\
1600 & 0.10 & 90.9 & - \\
SEM & 0.0207 & 2.03 & - \\
$P$-value & 0.60 & 0.18 & - \\
Time, wk & & & \\
1 & 0.072 & 98.4 & 15 \\
2 & 0.083 & 98.5 & 86 \\
3 & 0.11 & 94.2 & 104 \\
4 & 0.078 & 96.3 & 229 \\
5 & 0.16 & 97 & 376 \\
6 & 0.057 & 86.1 & 754 \\
7 & 0.27 & 80.3 & 1,806 \\
SEM & 0.0284 & 3.71 & 27.3 \\
$P$-value & 0.0001 & 0.014 & 0.0001 \\
Hour $\times$ week $(P$-value $)$ & 0.82 & 0.27 & - \\
\hline
\end{tabular}

\footnotetext{
${ }^{1}$ Week 7 was greater $(P<0.05)$ than the other weeks that were not different from each other.

${ }^{2}$ Week 6 and 7 did not differ but were lower $(P<0.05)$ than the other weeks that were not different from each other.

${ }^{3}$ DMI from starter intake increased $(P<0.05)$ weekly.
}

were greater $(P<0.02)$ than values during wk 6 and 7. Intake of starter $(\mathrm{g} / \mathrm{d})$ increased with week $(P<$ 0.0001).

Blood BHB, glucose (Figure 1a and 1b), and the ratio of glucose to BHB were averaged within calf by day and regressed against starter intake. Blood BHB increased $\left(P=0.02 ; \mathrm{R}^{2}=0.28\right)$, blood glucose decreased $(P=$ $\left.0.02 ; \mathrm{R}^{2}=0.23\right)$, and the ratio of blood glucose to BHB decreased $\left(P=0.01 ; \mathrm{R}^{2}=0.17\right)$ with increasing starter intake. However, the $\mathrm{R}^{2}$ were low for each relationship. Blood BHB and glucose in wk 7 were regressed against total (accumulated) starter intake over the first $7 \mathrm{wk}$, and no linear $\left(P>0.81, \mathrm{R}^{2}<0.1\right)$ relationship was present.

\section{Effect of Stress}

Blood BHB from 1200 and $1600 \mathrm{~h}$ samples after the vaccine were lower $(P<0.05)$ than the 4 sample times before the vaccine (Table 3 ). Blood glucose was not affected $(P>0.05)$.

\section{Effect of Starter Restriction}

Blood BHB was greater $(P<0.01)$ for 1600 than $1200 \mathrm{~h}$ and tended $(P<0.08)$ to be greater for 0800 than $1200 \mathrm{~h}$ (Table 4). On d 61, 62, and 63 of this measurement period, calves restricted on d 60 and 61 had lower $(P<0.05)$ blood BHB than calves fed ad libitum. On d 64 and 65 of the measurement period, no differences were present in $\mathrm{BHB}$ among calves restricted or fed ad libitum starter.

Blood glucose was greater $(P<0.001)$ for 0800 than 1200 and $1600 \mathrm{~h}$. On d 61 and 62 of this measurement period, calves restricted in starter intake had lower $(P$ $<0.05)$ blood glucose than calves fed ad libitum. On d 63,64 , and 65 of the measurement period, no differences were present in glucose among calves restricted or fed ad libitum starter. Blood BHB increased $\left(P=0.01, \mathrm{R}^{2}\right.$ $=0.08)$ with increasing starter intake; however, the $\mathrm{R}^{2}$ was low (Figure 2a). Blood glucose increased $(P=0.01$; $\left.\mathrm{R}^{2}=0.23\right)$ with increasing starter intake; however, the $\mathrm{R}^{2}$ was low (Figure $2 \mathrm{~b}$ ).

The number of observations at each blood BHB concentration measured is reported by week in Table 5. During wk 7 , when calves were weaned and intakes were $\geq 1,251 \mathrm{~g} / \mathrm{d}, 38 \%$ of the $\mathrm{BHB}$ samples were $\leq 0.2 \mathrm{mmol} / \mathrm{L}$. During wk $>8$, again $38 \%$ of the BHB samples were $\leq 0.2 \mathrm{mmol} / \mathrm{L}$. Table 6 shows the number of observations at different blood BHB concentration within different intake ranges. Thirty percent of the blood BHB observations were $\leq 0.2 \mathrm{mmol} / \mathrm{L}$ for calves consuming $\geq 1,450 \mathrm{~g} / \mathrm{d}$ of starter. 


\section{Effect of Weaning Transition}

Blood BHB was influenced by day $(P<0.05)$, but not time of day, when sampled on d 40 to 44 , and was greater $(P<0.01)$ for high compared with low intake calves (Table 7$)$. A positive linear $\left(P=0.01, \mathrm{R}^{2}=\right.$ 0.06) relationship was observed of blood BHB to starter intake, when averaged within calf by time of day, with intake; however, the $\mathrm{R}^{2}$ was low (Figure 3a). Blood glucose was affected by time of day $(P<0.05)$, but not day, when sampled on d 40 to 44 , and was greater for high compared with low intake calves. A positive linear $\left(P=0.01, \mathrm{R}^{2}=0.23\right)$ relationship was observed of blood glucose to starter intake when averaged within calf by time of day, with intake; however, the $\mathrm{R}^{2}$ was low (Figure 3b). A negative linear $\left(P=0.01, \mathrm{R}^{2}=\right.$
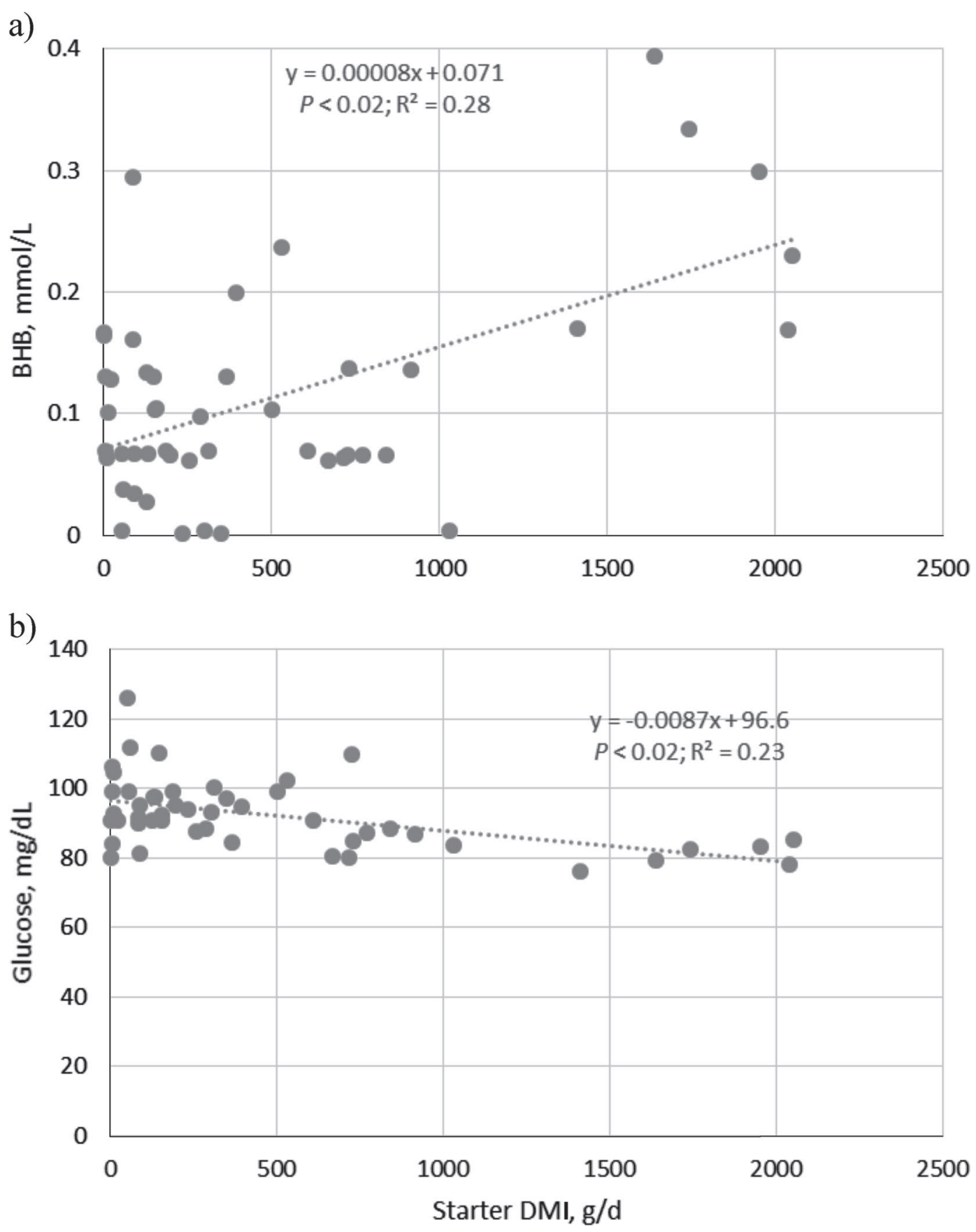

Figure 1. The relationship of (a) blood BHB and (b) blood glucose to starter intake during the first 7 wk of calf age in 6 calves in group 1. The 3 samples within a day were averaged by calf. 
0.19) relationship was observed of blood BHB to glucose ratio with starter intake, but again the $\mathrm{R}^{2}$ was low.

\section{Blood BHB}

Although blood BHB was related to starter intake, a large portion of this relationship is not accounted for as indicated by the low $\mathrm{R}^{2}$. Blood BHB measurements were low (less than $0.15 \mathrm{mmol} / \mathrm{L}$ ) during the first 6 wk, increased to approximately $0.25 \mathrm{mmol} / \mathrm{L}$ during wk 7 , and averaged no more than $0.36 \mathrm{mmol} / \mathrm{L}$ during d 61 to 65 in the first group of calves. Similar values were observed in the second group of calves on d 40 to 44 around the time of weaning on $\mathrm{d} 42$. The apparent increase in BHB in wk 7 could have been from the large increase in starter intake, more rumen fermentation with an increasing microbial population combined with increasing rumen size, and changes in the physiology to absorb and metabolize nutrients (Hird and Weidemann, 1964; Lane and Jesse, 1997; Rey et al., 2012). The vaccine and feed restriction affected BHB measurements by approximately $0.1 \mathrm{mmol} / \mathrm{L}$ and the effect of feed restriction lasted $2 \mathrm{~d}$ after feed restriction ended. During the last period when intake and BHB concentrations were the greatest, time of day affected the blood BHB concentration by approximately 0.05 $\mathrm{mmol} / \mathrm{L}$. The overall range of blood BHB was from 0 to $0.9 \mathrm{mmol} / \mathrm{L}$, with most samples being 0.1 to 0.4 $\mathrm{mmol} / \mathrm{L}$. Although blood BHB did positively relate to starter intake, it varied a lot within calves (low $\mathrm{R}^{2}$ ). Test strip measurements of BHB are reported in incre- ments of $0.1 \mathrm{mmol} / \mathrm{L}$, which is $>25 \%$ of the average maximum mean $(0.36 \mathrm{mmol} / \mathrm{L})$. Selecting either a cut point of $>0.2$ or $>0.3 \mathrm{mmol} / \mathrm{L}$ for blood $\mathrm{BHB}$ to recommend for weaning would result in large numbers of false positives or negative recommendations. Deelen et al. (2016) found strong linear relationships $(\mathrm{r}=0.9)$ of starter intake to BHB determined with a laboratory assay using 1-d measurements and 3- and 7-d averages. Deelen et al. (2016) suggested that $0.2 \mathrm{mmol} / \mathrm{L}$ on the Precision Xtra would be predictive of a 3 -d average consumption of $1 \mathrm{~kg}$ of starter per day. However, in their study, a measurement of $0.2 \mathrm{mmol} / \mathrm{L}$ with the laboratory assay covered a range from approximately 0.1 to $0.3 \mathrm{mmol} / \mathrm{L}$ on the Precision Xtra assay. Deelen et al. (2016) did not measure effects of time of day, stress, age, intake restriction, and weaning transition on the laboratory assay or Precision Xtra measurement of BHB. In the present study, the percentage of observations $\geq 0.2 \mathrm{mmol} / \mathrm{L}$ for wk 1 to 4 in group 1 was 17 , 33,33 , and $28 \%$, respectively, when starter intake was $<0.3 \mathrm{~kg} / \mathrm{d}$ (Table 5). Here using $0.2 \mathrm{mmol} / \mathrm{L}$ as a cut point would have resulted in many false positives. In $\mathrm{d}$ 40 to 44 in group 2, $50 \%$ of calves consuming $<1,000$ $\mathrm{g}$ of starter daily had blood BHB concentrations $\geq 0.2$ $\mathrm{mmol} / \mathrm{L}$ (Figure 3a), falsely indicating that the calves could be weaned. Forty-two percent of the calves consuming $>1,500 \mathrm{~g}$ of starter had BHB concentrations $<0.2 \mathrm{mmol} / \mathrm{L}$, falsely indicating that they should not be weaned (Figure 3a).

Eckert et al. (2015) observed higher blood BHB (measured on d 50) in calves weaned at $42 \mathrm{~d}$ versus

Table 3. Effect of time of day, day, and the challenge with a Pasteurella vaccine on blood BHB and glucose concentrations in 6 calves in group 1

\begin{tabular}{|c|c|c|c|c|}
\hline Item & & $\begin{array}{c}\mathrm{BHB}, \\
\mathrm{mmol} / \mathrm{L}\end{array}$ & $\begin{array}{l}\text { Glucose, } \\
\mathrm{mg} / \mathrm{dL}\end{array}$ & $\begin{array}{l}\text { DMI, } \\
\text { g/d }\end{array}$ \\
\hline \multicolumn{5}{|l|}{ Time, $\mathrm{h}$} \\
\hline 0800 & & 0.175 & 96.2 & - \\
\hline 1200 & & 0.092 & 94.8 & - \\
\hline 1600 & & 0.083 & 96.9 & - \\
\hline SEM & & 0.0395 & 3.40 & - \\
\hline$P$-value & & 0.22 & 0.16 & - \\
\hline \multicolumn{5}{|l|}{ Time, d } \\
\hline 34 & & 0.156 & 97 & 376 \\
\hline 36 & & 0.078 & 88.2 & 494 \\
\hline SEM & & 0.0322 & 2.71 & 100.4 \\
\hline$P$-value & & 0.105 & 0.05 & 0.42 \\
\hline Time, h & Time, $\mathrm{d}$ & & & \\
\hline 0800 & 34 & $0.167^{\mathrm{a}}$ & 100.3 & - \\
\hline 0800 & 36 & $0.183^{\mathrm{a}}$ & 92.0 & - \\
\hline 1200 & 34 & $0.167^{\mathrm{a}}$ & 98.8 & - \\
\hline 1200 & 36 & $0.017^{\mathrm{b}}$ & 90.7 & - \\
\hline 1600 & 34 & $0.133^{\mathrm{a}}$ & 91.8 & - \\
\hline 1600 & 36 & $0.033^{\mathrm{b}}$ & 82.0 & - \\
\hline Time $\times$ day $($ SEM $)$ & & 0.0563 & 4.94 & - \\
\hline Time $\times$ day $(P$-value $)$ & & 0.34 & 0.98 & - \\
\hline
\end{tabular}

$\overline{\mathrm{a}, \mathrm{b}}$ Values within a column with different superscripts differ $(P<0.05)$. 
Table 4. Effect of restricting intake on d 60 and 61 on blood BHB and glucose concentrations during 3 sampling times per day, day, restricted, and ad libitum fed groups of calves (6 calves/treatment) in group 1

\begin{tabular}{|c|c|c|c|c|}
\hline Item & Treatment & $\begin{array}{c}\mathrm{BHB}, \\
\mathrm{mmol} / \mathrm{L}\end{array}$ & $\begin{array}{c}\text { Glucose, } \\
\mathrm{mg} / \mathrm{dL}\end{array}$ & $\begin{array}{c}\text { DMI }^{1} \\
\text { g/d }\end{array}$ \\
\hline \multicolumn{5}{|l|}{ Time, h } \\
\hline 0800 & & $0.285^{\mathrm{ab}}$ & $89.8^{\mathrm{a}}$ & \\
\hline 1200 & & $0.257^{\mathrm{a}}$ & $82.2^{\mathrm{b}}$ & \\
\hline 1600 & & $0.318^{\mathrm{b}}$ & $81.5^{\mathrm{b}}$ & \\
\hline SEM & & 0.01772 & 2.25 & \\
\hline$P$-value & & 0.009 & 0.0001 & \\
\hline \multicolumn{5}{|l|}{ Time, d } \\
\hline 61 & & 0.236 & 81.2 & 2,371 \\
\hline 62 & & 0.297 & 84.2 & 2,939 \\
\hline 63 & & 0.311 & 86.5 & 2,988 \\
\hline 64 & & 0.272 & 85.3 & 3,053 \\
\hline 65 & & 0.317 & 85.3 & 3,295 \\
\hline SEM & & 0.02217 & 2.46 & 107.4 \\
\hline$P$-value & & 0.057 & 0.13 & 0.0001 \\
\hline \multicolumn{5}{|l|}{ Group } \\
\hline Normal & & 0.309 & 86.4 & 2,827 \\
\hline Restricted & & 0.264 & 82.7 & 3,032 \\
\hline SEM & & 0.01708 & 2.96 & 127.1 \\
\hline Group ( $P$-value) & & 0.086 & 0.39 & 0.28 \\
\hline \multicolumn{5}{|l|}{ Time, d } \\
\hline 61 & Ad libitum & $0.256^{\mathrm{a}}$ & $84.4^{\mathrm{a}}$ & 3,049 \\
\hline 61 & Restricted & $0.217^{\mathrm{b}}$ & $78.1^{\mathrm{b}}$ & 1,694 \\
\hline 62 & Ad libitum & $0.356^{\mathrm{a}}$ & $89.2^{\mathrm{a}}$ & 2,905 \\
\hline 62 & Restricted & $0.239^{\mathrm{b}}$ & $79.1^{\mathrm{b}}$ & 2,973 \\
\hline 63 & Ad libitum & $0.333^{\mathrm{a}}$ & $86.9^{\mathrm{a}}$ & 2,671 \\
\hline 63 & Restricted & $0.289^{\mathrm{b}}$ & $86.1^{\mathrm{a}}$ & 2,206 \\
\hline 64 & Ad libitum & $0.272^{\mathrm{a}}$ & $84.3^{\mathrm{a}}$ & 2,633 \\
\hline 64 & Restricted & $0.272^{\mathrm{a}}$ & $86.4^{\mathrm{a}}$ & 3,473 \\
\hline 65 & Ad libitum & $0.328^{\mathrm{a}}$ & $87.1^{\mathrm{a}}$ & 2,875 \\
\hline 65 & Restricted & $0.306^{\mathrm{a}}$ & $83.6^{\mathrm{a}}$ & 3,715 \\
\hline SEM & & 0.03135 & 3.48 & 151.8 \\
\hline Day $\times$ group $(P$-value $)$ & & 0.37 & 0.0448 & 0.0001 \\
\hline Time $\times$ day ( $P$-value $)$ & & 0.014 & 0.004 & - \\
\hline Time $\times$ group $(P$-value $)$ & & 0.74 & 0.11 & - \\
\hline Time $\times$ day $\times$ group $(P$-value $)$ & & 0.004 & 0.39 & - \\
\hline
\end{tabular}

${ }_{\mathrm{a}, \mathrm{b}}$ Means within a column and factor with different superscripts differ $(P<0.05)$.

${ }^{1}$ Hay intake averaged $3.6 \pm 1.1 \%$ of DMI.

calves still on milk to be weaned at $56 \mathrm{~d}$ of age, calves weaned at $42 \mathrm{~d}$ had greater starter intake than calves still on milk. Hence, weaning age affected blood BHB concentration. Rey et al. (2012) reported starter intake steadily increased with age. However, rumen butyrate concentrations were approximately $0.7 \mathrm{~m} M$ during the first $9 \mathrm{~d}$ of age and approximately $5 \mathrm{mM}$ from 10 to $83 \mathrm{~d}$ of age, not a steady increasing relationship with

Table 5. Number of observations ${ }^{1}$ at each blood BHB concentration by week in all phases of group 1

\begin{tabular}{|c|c|c|c|c|c|c|c|c|}
\hline \multirow{2}{*}{$\begin{array}{l}\mathrm{BHB}, \\
\mathrm{mmol} / \mathrm{L}\end{array}$} & \multicolumn{8}{|c|}{ Number of observations } \\
\hline & Wk 1 & Wk 2 & Wk 3 & Wk 4 & Wk 5 & Wk 6 & Wk 7 & $\mathrm{Wk}>8$ \\
\hline 0.9 & - & - & - & - & - & - & - & 1 \\
\hline 0.8 & - & - & - & - & - & - & - & - \\
\hline 0.7 & - & - & - & - & - & - & - & - \\
\hline 0.6 & - & - & - & - & - & - & 1 & 2 \\
\hline 0.5 & - & - & - & - & 2 & - & 3 & 3 \\
\hline 0.4 & - & 1 & - & - & - & - & 7 & 51 \\
\hline 0.3 & - & 1 & 1 & - & 1 & - & 11 & 55 \\
\hline 0.2 & 3 & 4 & 5 & 5 & 7 & 4 & 9 & 49 \\
\hline 0.1 & 7 & - & 6 & 4 & 1 & 2 & 4 & 13 \\
\hline 0 & 8 & 12 & 6 & 9 & 7 & 12 & 1 & 6 \\
\hline
\end{tabular}

${ }^{1}$ Three hundred twenty-four observations ranged from 0 to $0.9 \mathrm{mmol} / \mathrm{L}$ from wk 1 to d 65 . 
age or starter intake (Rey et al., 2012). Lane and Jesse (1997) reported that BHB production from isolated rumen epithelial cells was not strictly a function of VFA infused into the rumen. Giesecke et al. (1979) and Bush (1988) reported that BHB production from butyrate by rumen epithelial slices increased with age and was not a function of starter intake. Hird and Weidemann (1964) reported that butyrate metabolism to ketones is greater in large than small papillae and more of the ketones stay in large than small papillae rather than move into the muscle of the rumen epithelium. Also, they reported that $\mathrm{BHB}$ was metabolized to acetoacetate at a greater rate in the muscle than papillae side of the rumen epithelium. In calves fed MR only, blood BHB has been reported to increase to approximately 190\% of pre-meal concentrations $1 \mathrm{~h}$ after a meal (Senn et

a)

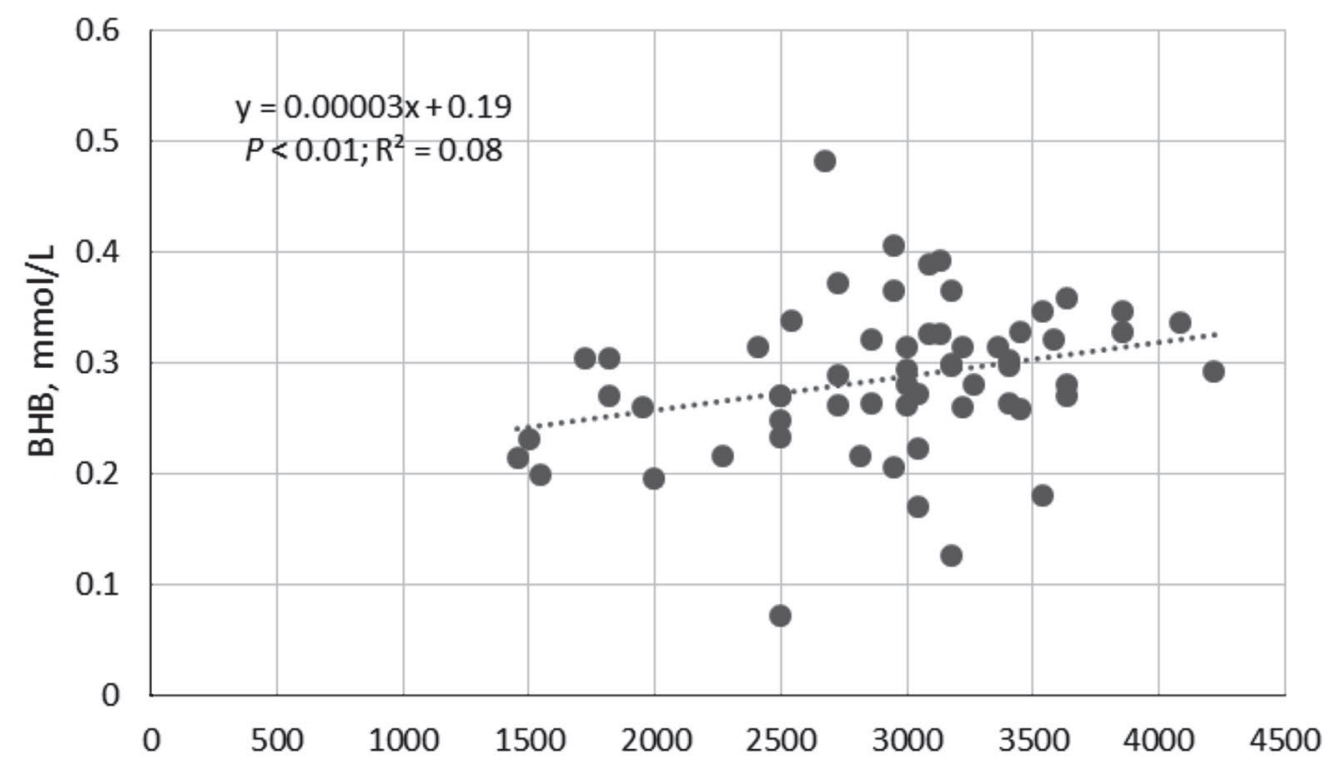

b)

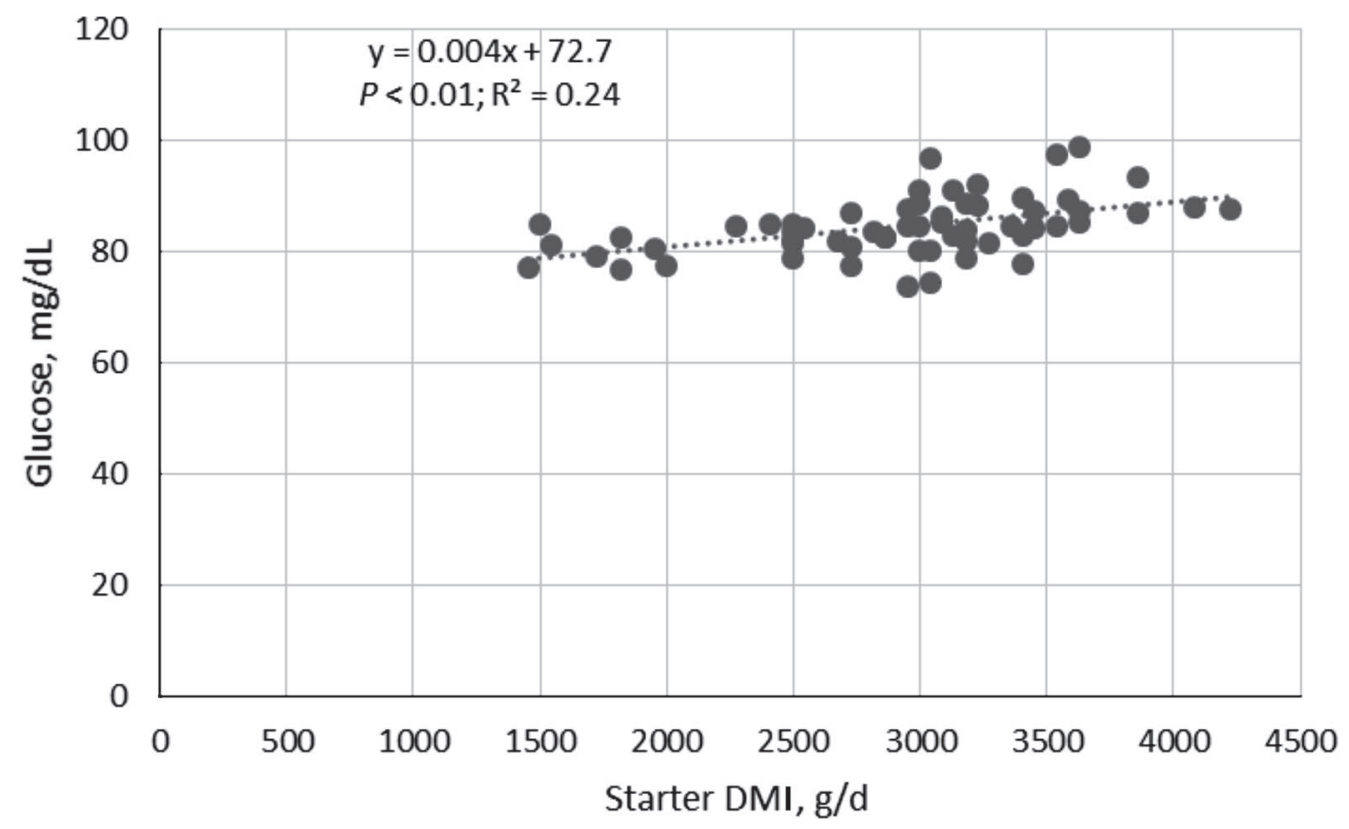

Figure 2. The relationship of (a) blood BHB and (b) blood glucose to starter intake during d 61 to 65 of calf age in 12 calves in group 1 . The 3 samples within a day were averaged by calf. 
Table 6. Blood BHB concentrations $(\mathrm{n}=60,3$ samples at different times of day were averaged) by ranges in starter intake in calves $\geq 8$ wk of age in group 1

\begin{tabular}{|c|c|c|c|c|c|}
\hline \multicolumn{2}{|c|}{ Starter intake } & \multicolumn{4}{|c|}{ Observed BHB (mmol/L), no. } \\
\hline $\mathrm{g} / \mathrm{d}$ & $\begin{array}{c}\text { No. of } \\
\text { observations }\end{array}$ & $\leq 0.1$ & 0.2 & 0.3 & $\geq 0.4$ \\
\hline$<1,500$ & 2 & - & 2 & - & - \\
\hline $1,500-1,999$ & 6 & - & 2 & 3 & 1 \\
\hline $2,000-2,499$ & 7 & 1 & 1 & 1 & 4 \\
\hline $2,500-2,999$ & 15 & - & 1 & 4 & 10 \\
\hline $3,000-3,499$ & 20 & 1 & 3 & 8 & 8 \\
\hline $3,500-3,999$ & 8 & - & 3 & 3 & 2 \\
\hline$>3,999$ & 2 & - & - & 2 & - \\
\hline
\end{tabular}

al., 2000), suggesting milk or MR intake may interfere with using blood BHB to predict starter intake. Thus, for many reasons related to metabolism in the young calf, blood BHB may not have a direct relationship to starter intake.

With the variation observed in blood BHB concentrations, potential effect of stress, intake restriction, weaning, time of day when the sample was taken, and small $0.1 \mathrm{mmol} / \mathrm{L}$ increment of the test, the test strip has too many limitations to be a proxy for starter intake in calves. No good cut point can be determined without having many false positives or negatives.

\section{Blood Glucose}

Variation of blood glucose among calves was large. Blood glucose decreased with age and starter intake within the first $7 \mathrm{wk}$ and increased with starter intake in d 61 to 65 . During d 61 to 65 , it changed with time of day and declined on days with feed restriction. This

Table 7. Effect of hour of day and day on blood BHB and glucose and starter DMI in group 2

\begin{tabular}{llcc}
\hline Item & $\begin{array}{c}\text { BHB, } \\
\text { mmol/L }\end{array}$ & $\begin{array}{c}\text { Glucose, } \\
\mathrm{mg} / \mathrm{dL}\end{array}$ & $\begin{array}{c}\text { DMI, } \\
\mathrm{g} / \mathrm{d}\end{array}$ \\
\hline $\begin{array}{l}\text { Time, } \mathrm{h} \\
0800\end{array}$ & 0.23 & $78.1^{\mathrm{a}}$ & - \\
1200 & 0.19 & $86.0^{\mathrm{b}}$ & - \\
1600 & 0.17 & $88.9^{\mathrm{b}}$ & - \\
SEM & 0.039 & 4.72 & - \\
$P$-value & 0.18 & 0.04 & - \\
Time, $\mathrm{d}$ & & & \\
40 & $0.11^{\mathrm{a}}$ & 90.6 & 1,151 \\
41 & $0.15^{\mathrm{ab}}$ & 83.8 & 1,193 \\
43 & $0.31^{\mathrm{c}}$ & 85.3 & 1,486 \\
44 & $0.23^{\mathrm{bc}}$ & 77.6 & 1,502 \\
SEM & 0.049 & 5.24 & 302 \\
$P$-value & 0.02 & 0.13 & 0.06 \\
Hour $\times$ day $(P$-value $)$ & 0.42 & 0.31 & - \\
\hline
\end{tabular}

\footnotetext{
${ }^{\mathrm{a}-\mathrm{c}}$ Means for BHB with different superscripts differed for day, and means with different superscripts for glucose differed by hour $(P<$ $0.05)$.
}

changing relationship with starter intake makes it an unreliable proxy of starter intake. As is known, blood glucose is arriving in the blood during the pre-weaned period primarily from consumption of MR and only changed in wk 6 and 7 during weaning from MR and postweaning. In calves fed MR only, blood glucose has been reported to increase to approximately $140 \%$ of pre-meal concentrations $1 \mathrm{~h}$ after a meal (Senn et al., 2000), suggesting that milk or MR intake may interfere with using blood glucose to predict starter intake.

With the first group of calves, when starter intake was $>1,381 \mathrm{~g} / \mathrm{d}$, blood glucose ranged from 74 to $96 \mathrm{mg} /$ $\mathrm{dL}$ and ranged from 80 to $126 \mathrm{mg} / \mathrm{dL}$ when $<1,381 \mathrm{~g} / \mathrm{d}$ (Figure 1b). With the second group of calves around weaning ( 40 to $44 \mathrm{~d}$ of age), blood glucose ranged from 73 to $97 \mathrm{mg} / \mathrm{dL}$ with intakes $>1,452 \mathrm{~g} / \mathrm{d}$. These ranges in blood glucose do not allow one to determine a valid cut-point for starter intake to wean without having a large percentage of false positives or negatives.

The ratio of blood glucose to BHB to starter intake was analyzed in calves fed MR because BHB increases whereas glucose decreases with age. The ratio of blood glucose to BHB to starter intake was variable and no better predictor of starter intake than blood glucose or BHB alone. Additionally, the relationship of blood glucose to starter intake increased with increasing starter intake in the weaned calf (Figure 2b), further distorting how glucose could be used to predict starter intake. No good cut point can be determined without having many false positives or negatives.

We observed a linear relationship of blood BHB to increase with increasing starter intake; however, starter intake was not the only factor influencing blood BHB as indicated by the low $\mathrm{R}^{2}$. In a farm-use setting, a blood sample would likely be taken from a calf or calves by a farm advisor during a visit. The sample from one calf would be subject to many of the items tested herein (age, time of day when blood was sampled, stress, weaning, and intake restriction, as well as starter intake). Between the variability associated with these items and 
a)

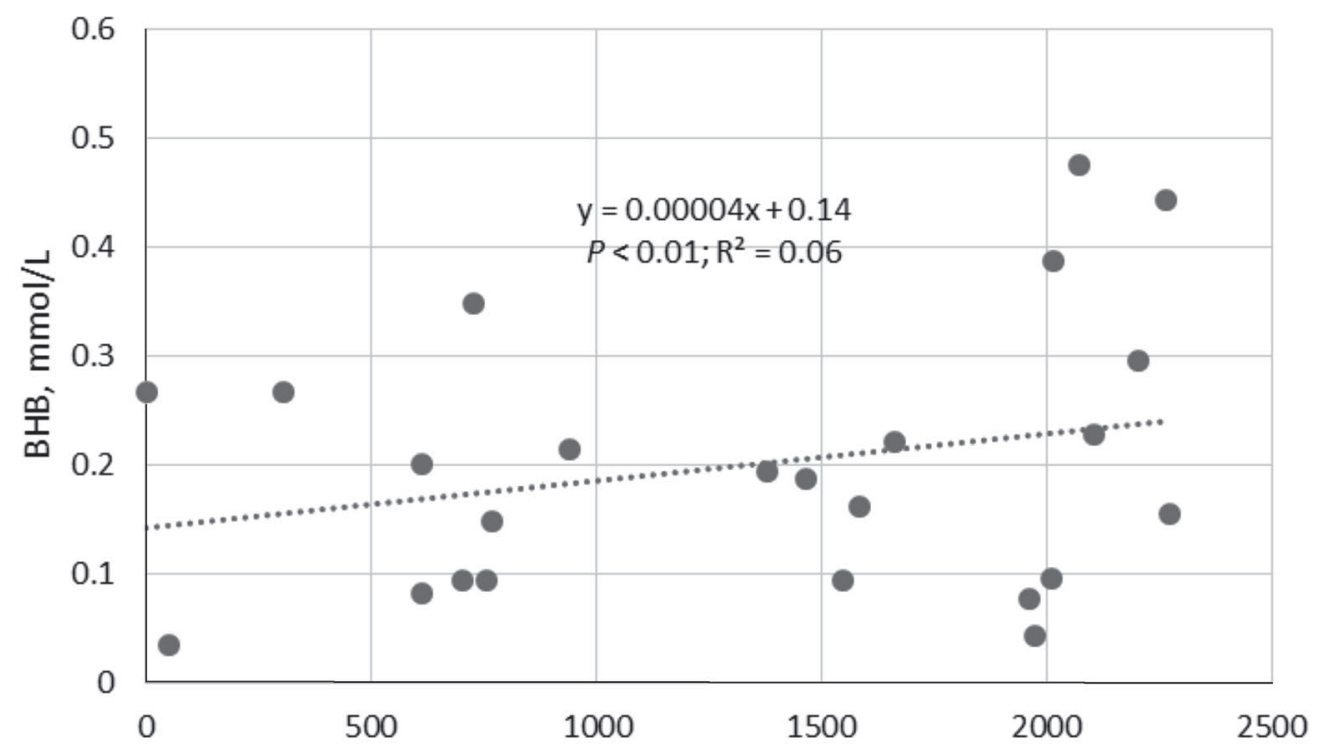

b)

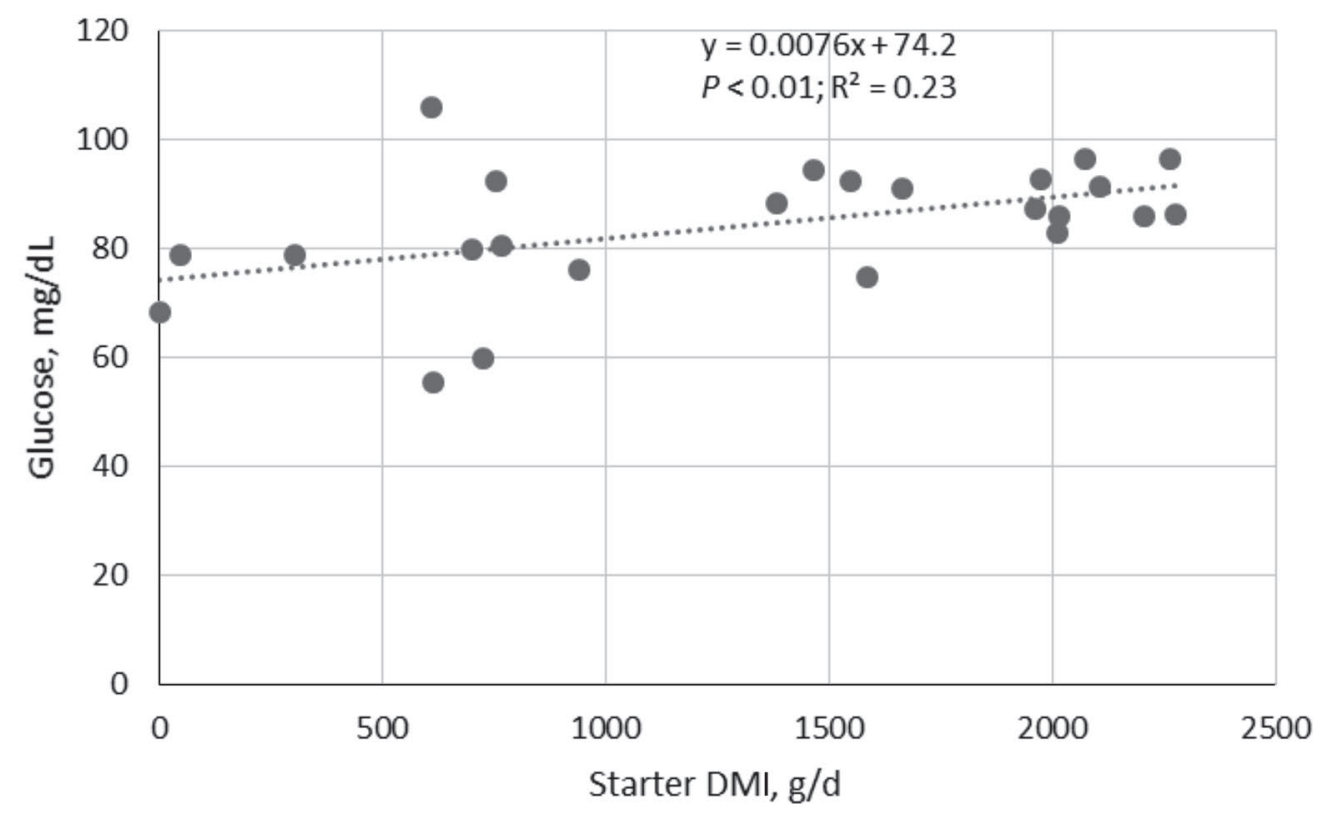

Figure 3. The relationship of (a) blood BHB and (b) blood glucose to starter intake in group 2 between 40 and $44 \mathrm{~d}$ of age. The 3 daily samples were averaged by calf.

large increment of BHB with the test strip system (0.1 $\mathrm{mmol} / \mathrm{L}$ out of a cut point of either 0.2 or $0.3 \mathrm{mmol} / \mathrm{L})$, the usefulness of measuring blood BHB and glucose will be clouded by considerable uncertainty.

\section{ACKNOWLEDGMENTS}

This research was fully funded by Provimi (Brookville, $\mathrm{OH})$.

\section{REFERENCES}

AOAC International. 2000. Official Methods of Analysis. Vol. I. 17th ed. AOAC International, Arlington, VA.

Bach, K. D., W. Heuwiesder, and J. A. A. McArt. 2016. Technical note: Comparison of 4 electronic handheld meters for diagnosing hyperketoemia in dairy cows. J. Dairy Sci. In press.

Baldwin, R. L., K. R. McLeod, J. L. Klotz, and R. N. Heitmann. 2004. Rumen development, intestinal growth and hepatic metabolism in the pre- and postweaning ruminant. J. Dairy Sci. 87:E55-E65. 
Bush, R. S. 1988. Effect of age and diet on in vitro metabolism in rumen epithelium from Holstein calves. Can. J. Anim. Sci. 68:12451251.

Deelen, S. M., K. E. Leslie, M. A. Steele, E. Eckert, H. E. Brown, and T. J. DeVries. 2016. Validation of a calf-side $\beta$-hydroxybutyrate test and its utility for estimation of starter intake in dairy calves around weaning. J. Dairy Sci. 99:7624-7633.

Dubois, M., K. A. Gilles, J. K. Hamilton, P. A. Rebers, and F. Smith. 1956. Colorimetric method for determination of sugars and related substances. Anal. Chem. 28:350-356.

Eckert, E., H. E. Brown, K. E. Leslie, T. J. DeVries, and M. A. Steele. 2015. Weaning age affects growth, feed intake, gastrointestinal development, and behavior in Holstein calves fed an elevated plane of nutrition during the preweaning stage. J. Dairy Sci. 98:6315-6326.

FASS. 2010. Guide for the Care and Use of Agricultural Animals in Research and Teaching. 3rd ed. Federation of Animal Science Societies, Champaign, IL.

FDA. 2015a. 510(k) Substantial equivalence determination decision summary, assay and instrument combination template. $510(\mathrm{k})$ number: k122688. Accessed Nov. 3, 2015. http://www.accessdata. fda.gov/cdrh_docs/reviews/K122688.pdf.

FDA. 2015b. 510(k) Substantial equivalence determination decision summary, assay and instrument combination template. $510(\mathrm{k})$ number: k091547. Accessed Nov. 3, 2015. http://www.accessdata. fda.gov/cdrh_docs/reviews/K091547.pdf.

FDA. 2015c. $510(\mathrm{k})$ Substantial equivalence determination decision summary assay and instrument combination template. $510(\mathrm{k})$ number: k080960. Accessed Nov. 3, 2015. http://www.accessdata. fda.gov/cdrh_docs/reviews/K080960.pdf.

FDA. 2015d. 510(k) Substantial equivalence determination decision summary assay and instrument combination template. $510(\mathrm{k})$ number: k130094. Accessed Nov. 3, 2015. http://www.accessdata. fda.gov/cdrh_docs/reviews/K130094.pdf.

Giesecke, D., U. Beck, S. Wiesmayer, and M. Stangassinger. 1979 The effect of rumen epithelial development on metabolic activities and ketogenesis by the tissue in vitro. Comp. Biochem. Physiol. B 62:459-463.

Hall, M. B. 2009. Analysis of starch, including maltooligosaccharides, in animal feeds: A comparison of methods and a method recommended for AOAC collaborative study. J. AOAC Int. 92:42-49.

Hill, T. M., J. M. Aldrich, R. L. Schlotterbeck, and H. G. Bateman II. 2006. Effects of feeding calves different rates and protein concentrations of twenty percent fat milk replacers on growth during the neonatal period. Prof. Anim. Sci. 22:252-260.

Hill, T. M., H. G. Bateman II, J. M. Aldrich, and R. L. Schlotterbeck. 2009. Effect of weaning age of dairy calves fed a conventional or more optimum milk replacer program. Prof. Anim. Sci. 25:619-624.
Hill, T. M., J. D. Quigley, H. G. Bateman II, F. X. Suarez-Mena, T. S. Dennis, and R. L. Schlotterbeck. 2016. Effect of milk replacer program on calf performance and digestion of nutrients in dairy calves to 4 months of age. J. Dairy Sci. 99:8103-8110.

Hird, F. J. R., and M. J. Weidemann. 1964. Transport and Metabolism of Butyrate by Isolated Rumen Epithelium. Biochem. J. 92:585-589.

Iwersen, M., U. Falkenberg, R. Voigtsberger, D. Forderung, and W. Heuwieser. 2009. Evaluation of an electronic cowside test to detect subclinical ketosis in dairy cows. J. Dairy Sci. 92:2618-2624.

Klehr, K., M. Scherping, G. Stoddard, and G. Cramer. 2015. A comparative evaluation of 2 cow side meters and a milk test for the diagnosis of subclinical ketosis. Am. Assoc. Bov. Pract. Proc. 48:267-268. (Abstr.)

Lane, M. A., and B. W. Jesse. 1997. Effect of volatile fatty acid infusion on development of the rumen epithelium in neonatal sheep. J. Dairy Sci. 80:740-746.

Littell, R. C., P. R. Henry, and C. B. Ammerman. 1998. Statistical analysis of repeated measures data using SAS procedures. J. Anim. Sci. 76:1216-1231.

Pineda, A., and F. C. Cardoso. 2015. Technical note: Validation of a handheld meter for measuring B-hydroxybutyrate concentration in plasma and serum of dairy cows. J. Dairy Sci. 98:8818-8824.

Quigley, J. D., J. K. Bernard, T. L. Tyberendt, and K. R. Martin 1994. Intake, growth, and selected blood parameters in calves fed calf starter via bucket or bottle. J. Dairy Sci. 77:354-357.

Quigley, J. D., L. A. Caldwell, O. D. Sinks, and R. N. Heitmann. 1991. Changes in blood glucose, nonesterified fatty acids, and ketones in response to weaning and feed intake in young calves. J. Dairy Sci. 74:250-257.

Rey, M., F. Enjalbert, and V. Monteils. 2012. Establishment of ruminal enzyme activities and fermentation capacity in dairy calves from birth through weaning. J. Dairy Sci. 95:1500-1512.

Robertson, J. B., and P. J. Van Soest. 1981. The detergent system of analysis and its application to human foods. Pages 123-158 in The Analysis of Dietary Fiber in Food. W. P. T. James and O. Theander, ed. Marcel Dekker, New York, NY.

Senn, M., S. Gross-Lüem, H. Leuenberger, and W. Langhans. 2000. Meal patterns and meal-induced metabolic changes in calves fed milk ad lib. Physiol. Behav. 70:189-195.

Suarez-Mena, F. X., T. M. Hill, A. J. Heinrichs, H. G. Bateman, J. M. Aldrich, and R. L. Schlotterbeck. 2011. Effects of including corn distillers dried grains with solubles in dairy calf feeds. J. Dairy Sci. 94:3037-3044.

Van Soest, P. J., J. B. Robertson, and B. A. Lewis. 1991. Methods for dietary fiber, neutral detergent fiber, nonstarch polysaccharides in relation to animal nutrition. J. Dairy Sci. 74:3583-3597. 